\title{
DIVERSITY OF FLUIDS IN THE ORIGIN OF THE CHAPADA CU-AU DEPOSIT, GOIÁS.
}

\author{
RAUL MINAS KUYUMJIAN
}

\begin{abstract}
RESUMO A DIVERSIDADE DOS FLUÍDOS NA ORIGEM DO DEPÓSITO DE CU-AU DE CHAPADA, GOlAs O deposito de Cu-Au de Chapada, Goias, é hospedado por rochas da Sequencia Vulcano-Sedimentar de Mara Rosa, de idade neoproterozdica. O minério ocorre intimamente associado a zonas de alteração hidrotennal, sendo que ambos são controlados por fraturamento, mais intense nas proximidades de contactos de corpos intrusivos e zonas de falhas regionais. O estagio inicial da mineralização consistiu de reações entre água do mar aquecida e basaltos da sequencia de Mara Rosa (fluido hidrotermal exalativo), com lixiviação de metais das rochas basalticas e deposição em zonas de alteração hidrotermal. Posteriormente, fluido hidrotermal, originado de intrusoes dioriticas pequenas lixiviou metais de rochas encaixantes, cuja deposição enriqueceu a mineralização. Finalmente, fluidos metamorficos, gerados durante a orogenese brasiliana, formaram veios de quartzo auriferos em aieas próximas a Chapada.
\end{abstract}

Palavras-chave: Depósito cobre-ouro, fluidos mineralizantes, Chapada

ABSTRACT The Chapada Cu-Au deposit, Goiás, is located in the Neoproterozoic Mara Rosa volcanosedimentary sequence. Mineralization is closely associated with hydrothermal alteration and the location of both is controlled by fracturing which is best developed along intrusive contacts and within fault zones. The initial genetic stage involved reactions between heated seawater and basalts in the Mara Rosa sequence (exhalative hydrothermal fluid), and leaching and deposition of metals. Subsequently, magmatic hydrothermal fluids accompanied small dioritic intrusions that were late but co-magmatic in the volcano-sedimentary sequence evolution. This fluid leached metals from favorable source rocks and probably penetrated the earlier mineralized hydrothermal zone. Finally, metamorphogenic fluids, generated during the Brasiliano orogeny, formed gold enriched quartz veins near the Chapada area.

Keywords: Copper-gold deposit, mineralizing fluids, Chapada

INTRODUCTION The Neoproterozoic Mara Rosa volcano-sedimentary sequence has the following occurrences: Zacarias stratiform syngenetic gold deposit (Arantes et al. 1991), Posse epigenetic gold deposit (Arantes et al. 1991) and Chapada copper-gold deposit. According to Richardson et al. (1986), geologic and chemical features at Chapada suggest that ore zones represent the remains of a porphyry copper system in which most of the ore was hosted by wall rock. Kuyumjian (1991) suggested that Chapada deposit represents a metamorphosed hydrothermal exhalative stratiform mineralization process. A reinterpretation of the ore genesis based on petrographic and field geologic data is presented, with the proposal that the mineralizations at Chapada region was related to exhalative, magmatic and metamorphic fluids.

GEOLOGY OF THE CHAPADA AREA The Chapada deposit is located in the Mara Rosa volcano-sedimentary sequence. This is part of a Neoproterozoic magmatic arc within the Massif of Goiás, which constitutes an internal massif developed as a micro-continent between the Guapore and Sao Francisco cratonic blocks during the Archean in central Brazil (Kuyumjian 1991, Pimentel and Fuck 1992, Pimentel et al. 1993).

Thrusted onto the Pilar de Goias Archean granite-greenstone belt terrane, the Mara Rosa sequence stratigraphy can be divided into three main belts referred to as the Eastern, Central and Western belts by Arantes et al. (1991). According to Kuyumjian (1989) throughout the Chapada region the Eastern Belt consists of metagrey wackes, sillimanite-staurolite-kyanite bearing schists, quartz-feldspathic biotite schists and gneisses (metamorphosed acid volcaniclastic rocks), garnet-biotite schists, metacherts, banded iron formations, calcsilicated rocks and exhalites, with intercalations of calcalkaline quartz amphibolites and quartz garnet amphibolites. The Central Belt stratigraphy is dominantly composed by tholeiitic diopside amphibolites, with strained pillows, epidote amphibolites and garnet amphibolites, with minor inter- calations of banded iron formation and metachert. The Western Belt consists dominantly of staurolite-kyanite-garnet bearing schists, feldspathic biotite gneisses and calc-silicated rocks. The sequence has been intruded by tonalites, granodiorites, gabbros, pyroxenites and hornblendites. Younger, post-metamorphic pegmatites, quartz veins and dykes of diabase crosscut the sequence.

Both metasedimentary and intrusive rocks have a conspicuous regional foliation imprinted by the Brasiliano event. The sequence trends northeasterly and dips to northwest, and the lithologies Have been metamorphosed to the amphibolite fades. Retrograde minerals and fabrics overprinting the peak metamorphic assemblages is not a common feature of the Chapada rocks, but sillimanite and white mica pseudomorphs of kyanite are found. Zircon U-Pb ages of $862 \pm 8 \mathrm{Ma}$ and $856+13 /-7$ Ma from felsic metavolcanic rock and metatonalite from Mara Rosa region, respectively, were obtained by Pimentel et al. (1993) and interpreted by the authors to represent the time of deposition of the rocks. Titanite from the metavolcanic rock yielded a recrystallization age of $632 \pm 4 \mathrm{Ma}$.

The geochemical characteristics of the amphibolites of the sequence and associated plutonic rocks suggest a tectonic setting similar to modern volcanic arc-back-arc in an oceanic subduction zone environment (Kuyumjian 1989, 1991).

\section{THE CHAPADA COPPER-GOLD DEPOSIT The}

main characteristics of the Chapada deposit have been described by Richardson et al. (1986) and Kuyumjian (1989). The ore zone is situated within the Eastern Belt and constitutes a $1.5 \mathrm{~km}$ long, $0.5 \mathrm{~km}$ wide and 80 meters thick low-grade $(0.44 \% \mathrm{Cu}, 0.35 \mathrm{~g} / \mathrm{t} \mathrm{Au})$, disseminated pyrite-chalcopyritemagnetite deposit associated with hydrothermal alteration. Pyrite is the dominant sulphide mineral and chalcopyrite is the only important ore mineral and frequently occurs intergrown with pyrite, magnetite and hematite. There are also bornite, chalcocite, sphalerite, galena, pyrrhotite and molybdenite. Gold is very fine and occurs in chalcopyrite and rarely in 


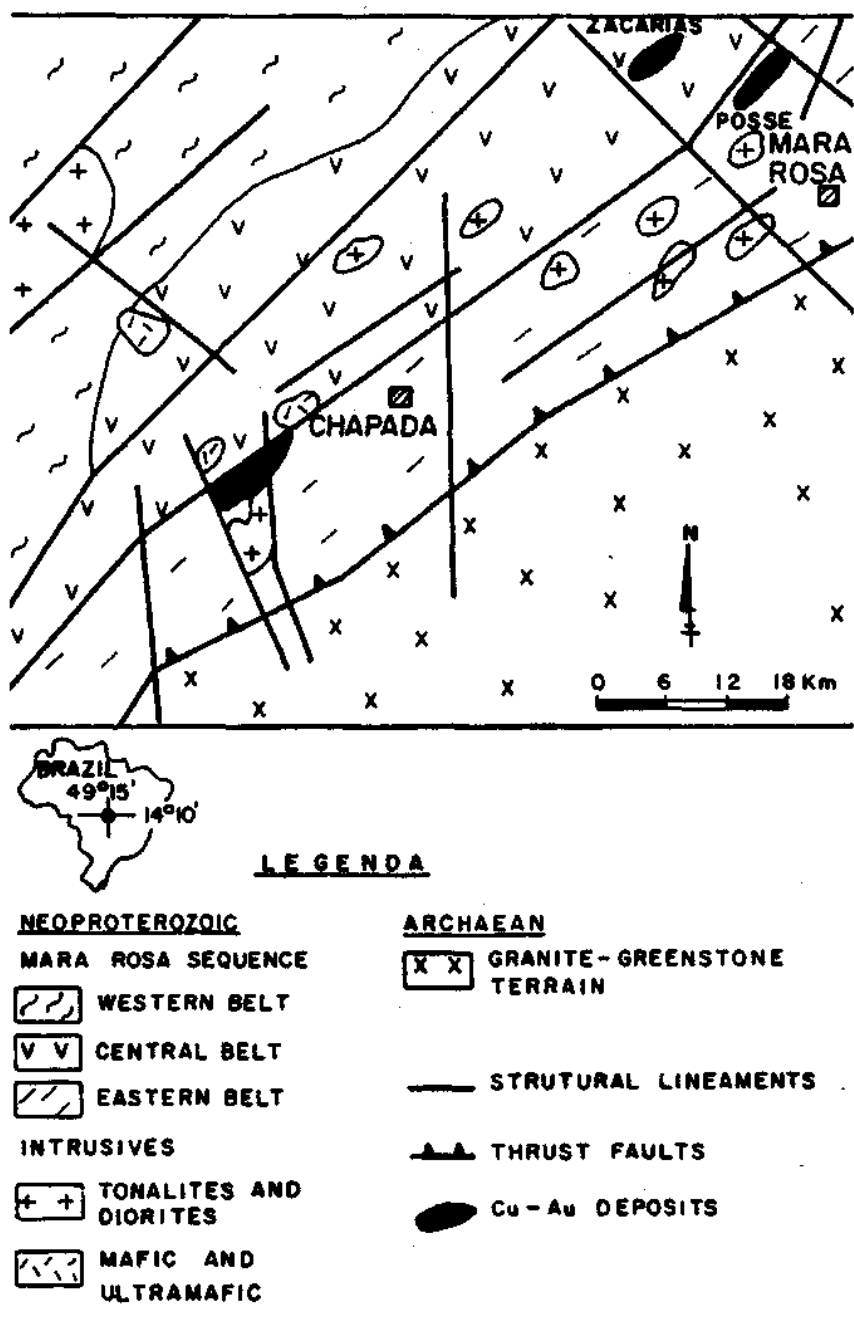

Figure 1-Simplified geologic map of the Chapada and Mam Rosa region, after Kuyumjian (1989) and Arantes et al. (1991).

Figura 1- Mapa geológico simplificado da região de Chapada e Mara Rosa, segundo Kuyumjian (1989) e Arantes et al. (1991)

between sulphide grains. The sulphides are frequently elongated in the same pattern as the other minerals, and in the microfolds and crenulations of the schistosity they are bent together with mica. They have also been boudinaged. These features, and the evidence that sulphides occur also as inclusions in metamorphic minerals indicate the pre-metamorphic nature of the Chapada mineralization.

Richardson et al. (1986) in their model assume that Chapada deposit is of the metamorphosed wall-rock porphyry copper type; but it seems they neglected evidence for rather localized intense hydrothermal interaction between fluids and basaltic rocks, which is represented by zones of epidosite (epidote+quartz+sphene) within amphibolites. We argue that these zones were sites of the intensive fluid-rock interaction that gave rise to hydrothermal fluids that probably were very important for the formation of the Chapada deposit.

GENETIC CONSIDERATIONS The deposit sequence comprises quartz-feldspathic biotite gneisses, feldspathic biotite schists, amphibolites of calc-alkaline affinity and the following products of hydrothermal alteration: epidoterich rocks, pyritic quartz-sericite schists and gedrite-rich schists. Alteration also includes very minor silicification, carbonatisation and potassic metassornatism. The last one is suggested by the presence of microcline in the biotite schists and gneisses, raising measured $\mathrm{K}_{2} \mathrm{O}$ contents to as high as $7.13 \%$. Exhalite (essentially magnetite+garnet) and thin beds of schists with abundant tourmaline occur interbedded with the sequence that hosts the hydrothermal zones and associated deposit.

The feldspathic biotite schists and quartz-feldspathic biotite schists have chemical composition similar to dacite (Kuyumjian 1989) and their prograde metamorphic assemblages include biotite, quartz, plagioclase, almandine, microcline, staurolite, kyanite, rutile, zircon and opaque minerals. The sericite schist shows a well-developed planar fabric defined by muscovite-rich layers containing pyrite, between more granular quartz-feldspar layers. Original igneous and/or sedimentary fabrics appear to be entirely lacking. The accessory phases include magnetite/ilmenite, staurolite, rutile and sulphides. The staurolite-gedrite rocks (mafic tuffs ?) contain up to $70 \%$ of modal gedrite and may represent a metamorphosed chloritic alteration.

Within the epidote-rich zone which extends regionally towards north and south, the amphibolites are striped and frequently have up to $60 \%$ of epidote in modal composition. Within this epidote-rich zone, there are narrow bands of pale yellow green rock here denominated epidosite. This is a fine to medium-grained rock consisting of a mosaic of anhedral epidote, lobate quartz, sphene and subordinated magnetite. Some bands contain almost only epidote and sphene. The rocks from the epidosite zones are very different from the epidote-rich metabasalts derived from hydrothermal alteration of oceanic basalts by seawater and described by Humphris and Thompson (1978). They also do not correspond in mineral assemblages to any of those deduced from experiments at varying water-rock ratios by Mottl (1983). These bands of epidosite probably represent reaction zones of major oreforming hydrothermal solutions (cf. Richardson et al. 1987). It is proposed that within these zones, descending seawater was heated and reacted with rock, transforming basalt to the striped epidote amphibolite and epidosite zones, and leaching metals. Magmatism during formation of the deposit was mainly intrusive, originating diorite-tonalite plutons that were late but co-magmatic in the Mara Rosa sequence evolution. $\mathrm{The} \mathrm{Cu}, \mathrm{Au}$ and other metals in the Chapada deposit were deposited also from fluids released by these intrusions, as indicated by $\mathrm{S}$ isotope composition of pyrite and chalcopyrite (Richardson et al. 1986). This fluid leached metals from favorable source rocks and probably penetrated the earlier mineralized hydrothermal zone.

Therefore, the metal suite of the Chapada mineralization probably was originally derived both by remobilization of basaltic rocks in a hydrothermal system, and from magmatic fluids released by the intrusions.

The history of the regional deformation in the Chapada region can be interpreted in terms of two major stages, the first of which is the isoclinal folds displaying hinge lines northeastward, and axial planes dipping towards the west. There is a penetrative foliation associated to the isoclinal folds, with the tabular and boudinaged ore zone lying parallel to it. The long axis of this roughly elipsoidal ore zone has a northeast trend. The kinematic of the first stage of deformation is illustrated by stretching lineation, asymmetric pressure shadows around kyanite porphyroclasts and development of S/C structures. The second stage of deformation, superimposed on the early isoclines and schistosity, has developed open broad folds* which was followed by the development of a crenulation cleavage along the planes generated during the first deformation. The deposit is controled by $\mathrm{N} 20^{\circ}-40^{\circ} \mathrm{E}$ shear zones, but subsidiary $\mathrm{N} 50^{\circ}-70^{\circ} \mathrm{E}, \mathrm{N} 10^{\circ} \mathrm{E}$ and $\mathrm{N} 20^{\circ}-40^{\circ} \mathrm{W}$ shear systems are also present. The axial elongation and 
principal planes orientation of the ore zone reflect the northeast axis alignment and westward dipping axial planes of the isoclinal folding of the first stage of deformation.

Araujo Filho (1992) suggested that the main tectonic lineaments in the Massif of Goiás resulted from two distinct compressive episodes during Neoproterozoic Brasiliano event from which thrusting and shear zones have developed. The first compressive episode, at the beginning of the Brasiliano tectono-thermal event, generated a strong tectonic transport from west to east. This event is marked by the occurrence of parallel shear zones, intense sheath-folding and fault-propagation-folds. The second compressive episode indicates a NNW towards SSE direction of tectonic transport, and it is characterized by duplex geometry, generating meso and megascopic thrusts within the supracrustal rocks. This episode is marked by the occurrence of transcurrent movements forming restricted shear zones, imbricated thrusts and interference fold patterns. It is responsible for the overthrusting of the Mara Rosa sequence on the Archean rocks and for the formation of $\mathrm{N} 50^{\circ}-75^{\circ} \mathrm{W}$ and $\mathrm{N} 45^{\circ}-60^{\circ} \mathrm{E}$ mega-shear zones and reactivation of $\mathrm{N} 40^{\circ}-50^{\circ} \mathrm{E}$ transcurrent faults. It is here proposed that the second tectonic event is responsible for the present metamorphic mineral association in the rocks of Chapada, including the hydrothermal alteration zones, and for the copper and gold deposits.

Although ore minerals at Chapada are disseminated in the host rocks and are never in obvious quartz veins or veinlets, gold enrichment in quartz veins associated with shear zones has been observed in the Mara Rosa sequence more to the north, at the Sorongo and Fil6 gold occurrences (Lacerda
1986). These veins probably were formed by filling of fractures and open cavities created during the late stage of the second compressive episode, implying that fluids derived from neighbouring rocks and were transported over rather short distances, probably during or after the relaxation of the second compressional episode stresses.

FINAL REMARKS The Chapada disseminated copper-gold deposit is located within metamorphosed hydrothermally altered calc-alkaline extrusive basaltic and dacitic rocks, in a intimate spatial association with intrusions of tonalitic and dioritic composition with calc-alkaline affinity, in a tectonic setting similar to modern volcanic arcs. It is here proposed that the Chapada $\mathrm{Cu}-\mathrm{Au}$ deposit was originally formed by interaction and then deposition from deep hidrothermal solution and from fluids released by the tonalite and diorite intrusions, followed by extensive metamorphogenic redistribution in shear zones related to the top-to-the-SE thrusting of the Upper Proterozoic Mara Rosa sequence over the Archean Pilar de Goias greenstone belt during the Neoproterozoic Brasiliano event. Gold enrichment is also locally found within late quartz veins croscutting the Mara Rosa sequence, implying that metamorphically derived fluids percolated the supracrustal rocks at the end of that event. It is concluded that the genetic histoy of the Chapada deposit began during deposition of the island-arc type Mara Rosa sequence but was completed only during the Brasiliano orogeny.

\section{REFERENCES}

ARANTES, D.; OSBORNE, G.A.; BUCK, P.S. 1991. The Mara Rosa volcano- sedimentary sequence and associated gold mineralization. In: Symp. Brazil Gold'91. Balkema, Rotterdam, 1991. Proceedings... Belo Horizonte. p. 221-229.

ARAUJO FILHO, J.O. de 1992. The Pireneus mega-inflection in Central Brazil: an example of a poly-deformed Brasiliano fold-thrust belt. In: GEO. LATEIN. KOL., Munster, 1992. Abstracts..Munster. p. 129

HUMPHRIS, S.E. \& THOMPSON, G. 1978. Trace element mobility during hydrothermal alteration of oceanic basalts. Geochim. Cosmochim. Acta, 42:121-136

KUYUMJIAN, R.M. 1989. The geochemistry and tectonic significance of amphibolitesfrom the Chapada sequence, central Brazil. London. 289 p. (PhD thesis, University of London, England).

KUYUMJIAN, R.M. 1991. A suggested hydrothermal exhalative origin for the Chapada copper-gold deposit, Brazil. In: SYMP. BRAZIL GOLD'91. Balkema, Rotter- dam, 1991. Proceedings...Belo Horizonte. p. 231-234.

LACERDA, H. 1986. As mineralizaQoes auriferas da regiSo de Mara Rosa (GO). Rev. Bras. Geoc., 16(3):274-284.

MOTTL, M.J. 1983. Metabasalts, axial hot springs, and the structure of hydrothermal systems at mid-ocean ridges. Geol. Soc. Am. Bull.94:161-180.
PIMENTEL, M.M. \& FUCK, R.A. 1992. Neoproterozoic crustal accretion in central Brazil. Geology, 20(4):375-379.

PIMENTEL, M.M.; FUCK, R.A.; MACHADO, N.; FUCK, R.F.; RIBEIRO, K.R.; VIANA, M.G. 1993. Dados geocronologicos U-Pb preliminares da regiao Mara Rosa, Goiás: implicates para ae"poca de mineralizacao de Au e para a evolucão tectonica Neoproteroz6ica no Centro-Oeste. In: CONOR. BRAS. GEOQ., 4. Brasilia, 1993. Anaw...Brasflia, SBGq. p. $255-258$.

RICHARDSON, C.J.; CANN, J.R.; RICHARDS, H.G.; COWAN, J.G. 1987. Metal-depleted root zones of the Troodos ore-forming hydrothermal systems, Cyprus. Earth Planetary Science Letters, 84:243-253.

RICHARDSON, S.V.: KESLER, S.E.; ESSENE, E.J. 1986. Origin and geochemistry of the Chapada $\mathrm{Cu}-\mathrm{Au}$ deposit, Goids, Brazil: a metamorphosed wall-rock porphyry copper deposit. Economic Geology, 81:1884-1898.

Manuscrito NB009

Recebido em 29 de fevereiro de 1996

Revisao do autor em 26 de setembro de 1996 Revisao aceita em 30 de setembro de 1996 